\title{
Chronic kidney disease mineral and bone disorder in children
}

\author{
Katherine Wesseling • Sevcan Bakkaloglu • \\ Isidro Salusky
}

Received: 14 May 2007 /Revised: 15 August 2007 / Accepted: 23 September 2007 / Published online: 28 November 2007

(C) IPNA 2007

\begin{abstract}
Childhood and adolescence are crucial times for the development of a healthy skeletal and cardiovascular system. Disordered mineral and bone metabolism accompany chronic kidney disease (CKD) and present significant obstacles to optimal bone strength, final adult height, and cardiovascular health. Decreased activity of renal 1 alpha hydroxylase results in decreased intestinal calcium absorption, increased serum parathyroid hormone levels, and high-turnover renal osteodystrophy, with subsequent growth failure. Simultaneously, phosphorus retention exacerbates secondary hyperparathyroidism, and elevated levels contribute to cardiovascular disease. Treatment of hyperphosphatemia and secondary hyperparathyroidism improves growth and high-turnover bone disease. However, target ranges for serum calcium, phosphorus, and parathyroid hormone $(\mathrm{PTH})$ levels vary according to stage of CKD. Since over-treatment may result in adynamic bone disease, growth failure, hypercalcemia, and progression of cardiovascular calcifications, therapy must be carefully adjusted to maintain optimal serum biochemical parameters according to stage of CKD. Newer therapeutic agents, including
\end{abstract}

\footnotetext{
K. Wesseling $\cdot$ I. Salusky

Pediatric Nephrology,

David Geffen School of Medicine at UCLA,

Los Angeles, CA, USA

S. Bakkaloglu

Pediatric Nephrology, Gazi University,

Ankara, Turkey

K. Wesseling $(\square)$

Pediatric Nephrology, UCLA,

2-383 MDCC, 650 Charles Young Drive,

Los Angeles, CA 90095, USA

e-mail: kwesseling@mednet.ucla.edu
}

calcium-free phosphate binding agents and new vitamin D analogues, effectively suppress serum PTH levels while limiting intestinal calcium absorption and may provide future therapeutic alternatives for children with CKD.

Keywords Osteodystrophy · Growth · Vascular calcification · Parathyroid hormone (PTH) - Vitamin D . $\mathrm{CKD}$ mineral and bone disorder Pediatrics

\section{Introduction}

Childhood and adolescence are crucial times for the development of a healthy skeletal and vascular system; alterations in bone modeling/remodeling or vascular biology in youth carry consequences that severely impact on quality of life as well as life span. In childhood, chronic kidney disease (CKD) causes disordered regulation of mineral metabolism, with subsequent alterations in bone modeling, remodeling, and growth. These alterations occur early in the course of CKD and are accompanied by the development of cardiovascular calcifications. Since growth failure and short stature are clinically apparent and concerning to patients, families, and physicians alike, optimization of growth and final adult height has been a focus of CKD management in children for decades. More recently, however, a growing awareness that cardiovascular calcifications accompany $\mathrm{CKD}$, that cardiovascular disease is the leading cause of mortality in both adults and children with kidney disease, and that therapies designed to treat the skeletal consequences of CKD affect the progression of vascular pathology, has led to a reclassification of the mineral, skeletal, and vascular disease associated with progressive kidney failure. Together, these alterations are termed "CKD mineral and bone disorder" ("CKD-MBD") [1]. 
The CKD-MBD is defined as a systemic disorder of mineral and bone metabolism due to CKD that is manifested by either one or a combination of the following: (1) abnormalities of calcium, phosphorus, parathyroid hormone (PTH), or vitamin D metabolism, (2) abnormalities in bone histology, linear growth, or strength, and (3) vascular or other soft tissue calcification. "Renal osteodystrophy" is the specific term used to describe the bone pathology that occurs as a complication of CKD and is, therefore, one aspect of the CKD-MBD. While the definitive evaluation of renal osteodystrophy requires a bone biopsy, this procedure is not routinely performed in the clinical setting. However, bone histomorphometry continues to be the gold standard for the assessment of three essential aspects of bone histology: turnover, mineralization, and volume [1].

Owing to new concepts and definitions of the mineral and bone alterations associated with $\mathrm{CKD}$, this review outlines the current understanding of abnormal bone and mineral metabolism in CKD and current treatment strategies and their impacts on different aspects of this disorder.

\section{Abnormalities of calcium, phosphorus, PTH, and vitamin $\mathrm{D}$ metabolism}

The kidneys regulate intestinal calcium absorption by converting 25-hydroxyvitamin $\mathrm{D}_{3}\left[25(\mathrm{OH}) \mathrm{D}_{3}\right]$, the storage form of vitamin $\mathrm{D}$, to 1,25 dihydroxyvitamin $\mathrm{D}_{3}[1,25$ $(\mathrm{OH})_{2} \mathrm{D}_{3}$, calcitriol], the active form of vitamin $\mathrm{D}$, by means of the enzyme $1 \alpha$ hydroxylase. Suppression of calcitriol synthesis occurs early in CKD, before alterations in calcium, phosphorus, or PTH levels can be detected $[2,3]$. Low circulating levels of calcitriol are due, in part, to a loss of functioning renal mass and result in decreased intestinal calcium absorption, stimulating a release of PTH [4-9]. In the early stages of CKD, elevated amounts of circulating PTH may result in normal or low serum phosphate levels. In advanced stages, however, decreased glomerular filtration rate limits phosphorus excretion. Hyperphosphatemia ensues, causing further suppression of $1 \alpha$ hydroxylase activity [10] and stimulation of PTH release [11, 12].

As renal function declines, the kidneys and skeleton become increasingly resistant to the actions of PTH, necessitating higher levels of PTH to maintain normal mineral and bone metabolism [13]. While the primary stimulus for PTH is serum calcium concentration, hyperphosphatemia also potentiates PTH secretion, while vitamin $\mathrm{D}$, acting through the vitamin $\mathrm{D}$ receptor in parathyroid gland tissue, suppresses PTH transcription. Over time, chronic hypocalcemia, hyperphosphatemia, and low circulating calcitriol levels result in parathyroid gland hyperplasia [14]. Since the half-life of parathyroid cells is long - on the order of 30 years - once established, hyperplasia is difficult to reverse. PTH secretion from enlarged parathyroid glands may become uncontrollable, due to the non-suppressible basal activity of a large number of parathyroid cells. Long-term stimulation of parathyroid glands may also lead to chromosomal changes that result in autonomous, unregulated growth and hormone release [15].

A recently described phosphaturic hormone, fibroblast growth factor 23 (FGF-23), may contribute to the pathogenesis of secondary hyperparathyroidism. FGF-23 was first identified in patients with tumor-induced osteomalacia, autosomal dominant hypophosphatemic rickets, and Xlinked hypophosphatemic rickets. In these conditions, elevated circulating levels of FGF-23 result in renal phosphate wasting and suppression of calcitriol production. FGF-23 levels rise as renal failure progresses, with markedly elevated levels present in individuals treated with dialysis [16]. In the early stages of CKD, increased serum FGF-23 levels are associated with suppression of calcitriol production and may thereby contribute to early stimulation of PTH release [17].

\section{Abnormalities in bone turnover, mineralization, volume, linear growth, or strength}

Evaluation of skeletal histology provides both a method for understanding the pathophysiology of renal bone disease and a guide to its proper management. The routine assessment of bone histology is not performed in the clinical setting; however, current recommendations from the National Kidney Foundation [Kidney Disease Outcomes Quality Initiative (KDOQI) Guidelines] suggest that a bone biopsy should be considered in all patients with CKD who have fractures with minimal trauma (pathological fractures), suspected aluminum bone disease, or persistent hypercalcemia despite having serum PTH levels between $400 \mathrm{pg} / \mathrm{ml}$ and $600 \mathrm{pg} / \mathrm{ml}$ (Level of Evidence: Opinion) [1, 18]. After double tetracycline labeling, bone tissue is obtained from the iliac crest on an outpatient basis with minimal morbidity $[19,20]$. As recently recommended by the Kidney Disease Improving Global Outcomes (KDIGO) workgroup, three areas of bone histology are examined: bone turnover, mineralization and volume, all of which may be altered in patients with CKD [1].

Bone turnover

Traditionally, renal osteodystrophy has been classified primarily on alterations in bone turnover. The primary 
lesion of renal osteodystrophy in children is one of high bone turnover, also termed "secondary hyperparathyroidism". Long-term exposure to high serum PTH levels often leads to fibrous changes in bones; this lesion is termed "osteitis fibrosa cystica". Since PTH activates the PTH/ parathyroid hormone-related protein (PTHrP) receptor on osteocytes and osteoblasts, increasing cellular activity of both osteoblasts and osteoclasts [21,22], excessive levels of circulating PTH result in increased bone turnover [23]. Increased bone turnover (secondary hyperparathyroidism) is evident in patients with early and advanced stages of CKD and is nearly universal in untreated children at the initiation of dialysis [24]. This condition is marked by increased numbers of osteoblasts and osteoclasts. Due to excess osteoclastic activity, increased resorption of mineral and matrix along trabecular surfaces and haversian canals is evident. Osteitis fibrosa cystica, the advanced lesion of secondary hyperparathyroidism, is also associated with peritrabecular fibrosis [25].

A state of low-turnover bone disease (adynamic renal osteodystrophy) also occurs in children treated with maintenance dialysis, although it has not been demonstrated in adults or children with earlier stages of CKD [26]. Adynamic bone results from over-suppression of serum PTH, due to excess treatment with vitamin D and calcium salts and is characterized by normal osteoid volume, an absence of fibrosis, and a reduced bone formation rate, as indicated by reduced or absent double tetracycline label on bone histology $[27,28]$. A paucity of osteoblasts and osteoclasts is present [23]. Adynamic bone has also been associated with low alkaline phosphatase levels, high serum calcium levels, and a propensity for increased vascular calcification $[29,30]$. In addition to the increased risk of fractures that is observed in adults with adyamic bone, adynamic bone in children treated with dialysis is associated with an increased severity of growth retardation [31, 32].

\section{Mineralization}

Alterations in skeletal mineralization are also prevalent in children with CKD [33]. Increases in unmineralized bone (osteoid), in conjunction with delayed rates of mineral deposition, are common [25, 33]. Defective mineralization that is associated with high-turnover bone disease is termed "mixed lesion"; when associated with low-to-normal bone turnover, it is referred to as "osteomalacia" [1]. While the implications of defective mineralization remain to be established, increased fracture rates, bone deformities, and growth retardation are prevalent in patients with CKD and may be due, in part, to altered mineralization.
Volume

Since PTH is an anabolic steroid at the level of trabecular bone, high levels of serum PTH are typically associated with increases in bone volume, trabecular volume, and trabecular width [20, 33-35]. Thus, children with CKD typically have normal or high bone volume as assessed by bone histomorphometry. Those treated with corticosteroids, however, may display loss of bone volume, termed "osteoporosis". The impact of osteoporosis in childhood may not always be immediately apparent; however, suboptimal peak bone mass accretion in adolescence is associated with an increased risk of osteoporosis, hip fractures, and mortality in adulthood [36].

\section{Growth}

Growth retardation is the hallmark of CKD in children. Protein and calorie malnutrition, metabolic acidosis, endorgan growth hormone resistance, and renal bone disease are the factors most commonly implicated in growth failure [37]. Despite correction of acidosis and anemia, normalization of serum calcium and phosphorus levels, and vitamin D sterol therapy replacement, the majority of children with CKD continue to grow poorly. Growth failure worsens as renal function declines; the average height of children with even mild CKD [glomerular filtration rate (GFR) $50-70 \mathrm{ml} / \mathrm{min}$ per $1.73 \mathrm{~m}^{2}$ body surface area] is 1 standard deviation score (SDS) below the average for healthy children. Moderate CKD (GFR 25-49 $\mathrm{ml} / \mathrm{min}$ per $1.73 \mathrm{~m}^{2}$ ) is associated with a height SDS of -1.5 , and, at the time of initiation of dialysis, the mean height SDS is $-1.8[38]$.

Secondary hyperparathyroidism contributes to growth retardation, although optimal target values for PTH in children in all stages of CKD remain controversial. In children with moderate $\mathrm{CKD}$, some data indicate that normal growth velocity is achieved when PTH levels are maintained within the normal range [39], while others have demonstrated a linear correlation between growth and PTH levels in the same patient population, those with the highest PTH values maintaining the highest rates of growth [40]. In children treated with maintenance dialysis, adynamic bone disease and growth failure have been associated with PTH levels around $100 \mathrm{pg} / \mathrm{ml}$ (1st generation assay), causing many experts to recommend target PTH levels 3-5 times the normal range in advanced CKD [32]. Data from the European community, however, have demonstrated that optimal growth velocity in this population may be associated with PTH levels of 2-3 times the normal range [41]. As a result, optimal PTH targets remain controversial, and recommendations vary between experts (Table 1). 
Table 1 Target PTH ranges by stage of CKD

\begin{tabular}{lll}
\hline CKD stage & $\begin{array}{l}\text { GFR range } \\
(\mathrm{ml} / \mathrm{min} \text { per } \\
\left.1.73 \mathrm{~m}^{2}\right)\end{array}$ & $\begin{array}{l}\text { Target intact PTH } \\
(\mathrm{pg} / \mathrm{ml})\end{array}$ \\
\hline 3 & $30-59$ & $* 35-70$ \\
4 & & $\$ 10-65$ \\
5 & $15-29$ & $* 70-110$ \\
& & $\$ 10-65$ \\
& $<15$ or dialysis & $* 200-300$ \\
& & $\$ 130-195$ \\
\hline
\end{tabular}

* recommended by [18], $\$$ recommended by [41]

Alterations in the growth hormone/insulin-like growth factor (IGF) pathway axis and their receptors also contribute to growth retardation. Despite normal or elevated circulating levels of growth hormone, decreased growth hormone receptor expression results in end-organ resistance. Furthermore, increased levels of IGF binding proteins, in the presence of normal IGF1 levels, result in decreased bioactivity of IGF1 [42-44].

Bone deformities are also common in uremic children, due to altered skeletal remodeling. Epiphyseal widening, particularly around wrists, ankles, and the costochondral junctions (rachitic rosary), is common in infants. Slipped epiphyses, genu valgum, and femoral and wrist deformities are most common in pre-adolescent children with longstanding CKD [24, 45]. Avascular necrosis of the femoral head and pathologic fractures of the extremities and chest wall due to osteoporosis and bone deformities may occur with minimal trauma. In addition, vertebral crush fractures contribute to significant morbidity in this population. The initial management of skeletal deformities requires the normalization of serum calcium, phosphorus, and PTH levels. Surgical correction is often also necessary but should be performed only after correction of biochemical abnormalities [18].

\section{Biomarkers of renal osteodystrophy}

Serum calcium and phosphorus

Serum calcium and phosphorus levels remain stable in mild-to-moderate stages of CKD. As renal failure advances, however, serum calcium levels drop in response to decreased intestinal calcium absorption resulting from low circulating levels of $1,25(\mathrm{OH})_{2} \mathrm{D}_{3}$ [2]. Treatment with active vitamin $\mathrm{D}$ sterols and phosphate binders corrects hypocalcemia, and, in stage $5 \mathrm{CKD}$, hypercalcemia may develop in response to aggressive treatment with high doses of vitamin D sterols and calcium-based phosphate binders. In this context, increased serum calcium, in conjunction with low levels of
PTH and alkaline phosphatase, may signal the development of adynamic bone [32]. Adjustment of vitamin D dosage and the use of non-calcium-containing phosphate binders can prevent the development of this complication as well as its associated growth failure [32]. Avoidance of increased serum calcium levels, which are associated with an increased risk of mortality in large populations of adult dialysis patients, also may prevent the progression of cardiovascular calcification (vide infra) [46, 47].

Similar to those of serum calcium, serum phosphorus levels remain within the normal range until CKD stages 4 to 5 are reached, when decreased GFR limits urinary phosphate excretion. Serum PTH levels rise but fail to compensate for phosphorus retention [2]. In stage $5 \mathrm{CKD}$, traditional hemodialysis or peritoneal dialysis typically removes less than half of ingested phosphate, necessitating the use of phosphate binders to control serum phosphorus and PTH levels. Since elevated values for the serum calcium $\times$ phosphorus product have been associated with vascular calcification and increased rates of mortality [4850], maintaining serum calcium and phosphorus levels within the normal range is important for optimizing cardiovascular health in all stages of CKD (vide infra) [18].

\section{Alkaline phosphatase activity}

Serum alkaline phosphatase values are fair markers of osteoblastic activity in children with CKD. Osteoblasts normally express large amounts of the bone isoenzyme of alkaline phosphatase, and elevated serum levels correlate with increased bone formation, high levels of serum PTH, and growth hormone therapy [51]. Since alkaline phosphatase is also present in the liver, elevated serum levels of total alkaline phosphatase may not always indicate increased bone turnover. Measurement of the heat-stabile and heat-labile fractions may help to separate skeletal from hepatic causes of elevated levels. Alkaline phosphatase measurements are useful in monitoring the skeletal response to treatment with vitamin $\mathrm{D}$ sterols in patients with osteitis fibrosa; values that decrease over several months usually indicate histologic improvement [52]. However, consistently low serum alkaline phosphatase values, particularly in children with stage $5 \mathrm{CKD}$ receiving large doses of vitamin D sterols and calcium-containing phosphate binders, are consistent with adynamic bone [32].

\section{Parathyroid hormone}

Serum PTH levels are widely used as non-invasive markers in distinguishing low-turnover lesions from osteitis fibrosa $[33,53]$. Current recommendations for target PTH levels are based on measurements obtained by the 1st generation PTH assay in cross-sectional bone biopsy data from children 
Table 2 Native vitamin D dosing by degree of D deficiency

\begin{tabular}{lll}
\hline Serum 25(OH) vitamin D $(\mathrm{ng} / \mathrm{ml})$ & Ergocalciferol $\left(\right.$ vitamin $\left.\mathrm{D}_{2}\right)$ dose & Comment \\
\hline$<5$ (severe deficiency) & $8,000 \mathrm{IU} / \mathrm{d}$ p.o. $\times 4$ weeks, then 4,000 IU/d $\times 2$ months & Measure 25(OH)D level after 3 months \\
$5-15$ (mild deficiency) & $4,000 \mathrm{IU} / \mathrm{d}$ daily p.o. $\times 12$ weeks & Measure 25(OH)D level after 3 months \\
$5-30$ (mild deficiency) & $2,000 \mathrm{IU} / \mathrm{d}$ daily p.o. $\times 12$ weeks & \\
\hline
\end{tabular}

treated with maintenance dialysis and receiving either lowdose oral calcitriol or no vitamin D sterol therapy. Since the 1st generation assays measure both full-length molecule and amino-terminally truncated fragments, 2nd generation PTH assays have been developed which measure, exclusively, the full-length molecule ("PTH(1-84)"). Although some data suggest improved ability of the newer 2nd generation assays to predict low-turnover bone disease [54], this finding has not been substantiated by others [34, $55]$.

Increasing skeletal resistance to the actions of PTH requires that $\mathrm{PTH}$ be maintained at higher levels in advanced stages of CKD [56-58] (Table 1). Downregulation of the PTH receptor, decreased expression of osteoblast differentiation factor, and increased levels of osteoclastogenesis inhibitory factor occur with decreased renal function, contributing to the skeletal resistance to $\mathrm{PTH}$ $[57,59]$. In patients with mild to moderate CKD, PTH levels that are within the normal range generally correspond to normal rates of bone formation, while mildly increased levels suggest the presence of secondary hyperparathyroidism [26]. In patients undergoing maintenance dialysis who are either untreated or are receiving small daily oral doses of calcitriol, PTH(7-84) levels of approximately two to five times the upper limit of normal generally correspond to normal bone formation rates $[26,33,41,53,60]$. Over-suppression of PTH in patients on dialysis has also been shown to result in growth failure, hypercalcemia, and adynamic bone [32]. In summary, PTH levels should be maintained in the range appropriate to the stage of CKD; levels appropriate for early stages of CKD would indicate low-turnover disease in patients treated with dialysis, while appropriate levels for stage $4 \mathrm{CKD}$ represent osteitis fibrosa in mild CKD.

\section{$25(\mathrm{OH})$ vitamin $\mathrm{D}$}

Careful attention to $25(\mathrm{OH})$ vitamin $\mathrm{D}$ (native vitamin D) nutrition is also fundamental to the optimal management of renal osteodystrophy [18]. Native vitamin D deficiency is prevalent in all children, including those with normal renal function [61], and the presence of renal insufficiency exacerbates this deficiency. Currently, therapeutic native vitamin $\mathrm{D}$ is available in two forms: vitamin $\mathrm{D}_{2}$ (ergocalciferol) is obtained from plants and vitamin $\mathrm{D}_{3}$ (chole- calciferol) is obtained from animal sources. Repletion of vitamin D stores has been shown to increase calcitriol production, ameliorate secondary hyperparathyroidism [62, 63], and heal lesions of poor mineralization in patients with CKD stages 2 through 4 [64]. Thus, assessment and repletion of native vitamin $\mathrm{D}$ stores are recommended in this population [18]. Of note, current dosage recommendations for native vitamin $\mathrm{D}$ repletion are similar to doses recommended for the treatment of nutritional rickets and far exceed recommendations for routine daily intake (Table 2).

\section{FGF-23}

FGF-23 is a newly described phosphaturic hormone associated with renal phosphate wasting [65], low serum $1,25(\mathrm{OH})_{2} \mathrm{D}_{3}$ levels, and osteomalacia in animals and humans with normal kidney function [66-68]. Levels increase as kidney disease progresses and are markedly elevated in patients treated with maintenance dialysis [16]. Current data indicate that increased levels correlate with calcitriol deficiency in adults with CKD stages 2 to 4 [17], that dietary phosphorus regulates serum levels of FGF-23 $[69,70]$, and that the administration of vitamin D sterols increases levels [71]. Furthermore, elevated pre-treatment values of serum FGF-23 may predict resistance of the

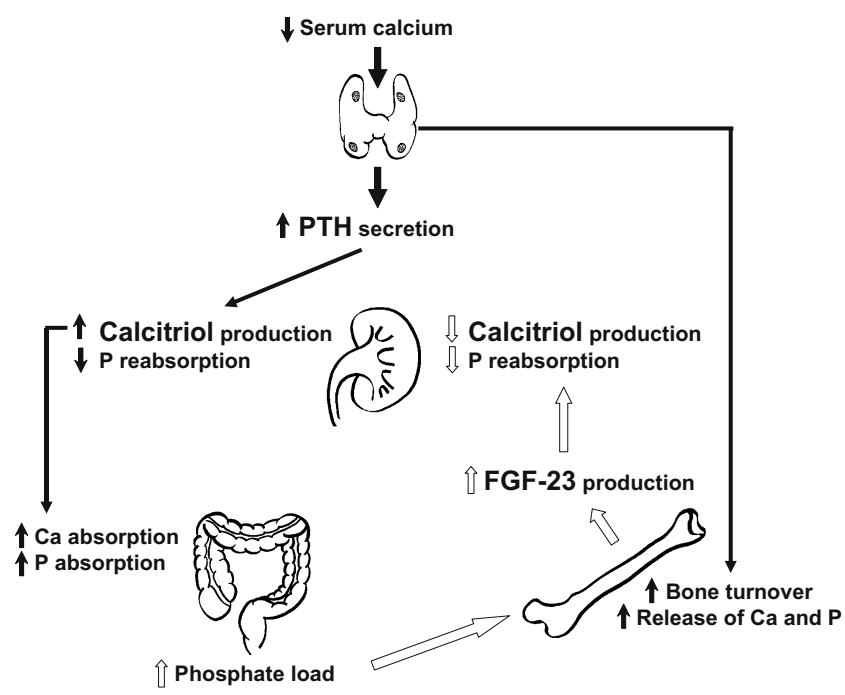

Fig. 1 Schematic representation of the interplay between PTH, FGF23 , and calcitriol in mineral metabolism in vivo. Solid arrows represent the actions of $\mathrm{PTH}$, while open arrows represent those of FGF-23 
parathyroid glands to therapy with vitamin D sterols $[72,73]$. These findings implicate a role for FGF-23 in the control of serum phosphorus and vitamin D metabolism, as well as in the pathogenesis of secondary hyperparathyroidism.

A schematic representation of the interplay between PTH, FGF-23, and calcitriol is depicted in Fig. 1.

\section{Vascular or other soft tissue calcification}

Extra-skeletal calcification, including vascular calcification, is prevalent in adults treated with dialysis [46, 47], has its origins in childhood [48, 49], and is associated with significant cardiovascular morbidity and mortality $[74,75]$. In contrast to the calcifications of atherosclerotic plaques in the vascular intima that develop with age in individuals with normal kidney function, vascular calcification in the uremic milieu develops primarily in the vascular media. Hypercalcemia, hyperphosphatemia, elevated levels of the calcium $\times$ phosphorus product, and high doses of vitamin D sterols [48-50] have all been implicated in the progression of the burden of extra-skeletal calcification. However, $40 \%$ of adult patients with stage $3 \mathrm{CKD}$, without these risk factors, show evidence of calcification [76], suggesting that factors in the uremic milieu itself, apart from high levels of calcium and phosphorus, contribute to cardiovascular disease. Furthermore, increased intimal-medial thickness of the carotid artery is present in both children on dialysis and in those with early stages of CKD [77], suggesting that vascular abnormality, the leading cause of death in this population, has its origins early in childhood CKD [78].

Although the mechanisms of the development of vascular calcification remain to be fully elucidated, osteoblasts and vascular smooth muscle cells have a common mesenchymal origin; core binding factor-1 (Cbfa1) is thought to trigger mesenchymal cell to osteoblast transformation. Mice deficient in Cbfal fail to mineralize bone [79], and arteries obtained from patients undergoing renal transplantation show increased levels of the protein [80]. Upregulation of the sodium-dependent phosphate transporter PIT-1 likely contributes to increased calcification [81, 82]. Furthermore, upregulation of pro-mineralization factors, such as osteopontin, bone sialoprotein, osteonectin, alkaline phosphatase, type I collagen, and bone morphogenic protein-2 (BMP-2), is potentiated by the uremic milieu [83-86], while expression of calcification inhibitors, such as fetuin A and matrix Gla protein, is suppressed [8789]. Levels of circulating FGF-23 may also contribute, as values are inversely correlated with peripheral vascular calcification in adult dialysis patients [90]. Treatment with high doses of calcium salts, in the form of calcium-based phosphate binders, has also been implicated in the progression of cardiovascular calcification in adult patients treated with maintenance dialysis, and this progression is prevented with the use of non-calcium-containing phosphate binders $[46,47]$.

\section{Treatment}

The goal of therapy in childhood CKD-MBD is to normalize mineral metabolism with the aim of improving growth and reducing bone deformities and fragility, while minimizing the progression of extra-skeletal calcification. Biochemical markers of serum calcium, phosphorus, and PTH are primarily used to guide therapy; current therapeutic agents are targeted to maintain values in the normal range for the stage of CKD (Table 1).

Phosphorus control

As a result of phosphorus retention in CKD stages 4 and 5 [91], patients with advanced CKD and those undergoing treatment with traditional maintenance dialysis regimensthrice-weekly hemodialysis or nightly peritoneal dialysisoften require dietary phosphate restriction as well as treatment with phosphate-binding agents. Serum phosphorus levels should be maintained within the appropriate range for age and, due to increased rates of growth, infants and young children must maintain higher levels of serum phosphorus than older children. Calcium-containing salts have been recommended as the mainstay in phosphorus binding therapy in CKD stages 3 through 5. While several calcium salts are widely used, including calcium carbonate, calcium acetate, and calcium citrate, calcium carbonate is currently the most commonly used compound [27, 92, 93]. In recent years, however, increasing concern about the progressive vascular calcifications associated with a positive calcium balance and hypercalcemia has led to the development of non-calcium-containing phosphate binders. Current recommendations suggest that total calcium intake from calcium-based phosphate binders should not exceed twice the recommended daily recommended intake (DRI) for dietary calcium. Elevated serum calcium levels (greater than $10.2 \mathrm{mg} / \mathrm{dl}$ ) should be treated by the withdrawal of calcium-based phosphate binder therapy and, if persistent, by the discontinuation of active vitamin D sterols [18].

To avoid excess calcium intake, a metal-free calciumfree phosphate binder, sevelamer hydrochloride (sevelamer $\mathrm{HCl}$, RenaGel) was developed. Although sevelamer is not yet approved for use in children, it has been shown in prospective trials to lower serum phosphorus levels effectively and control the skeletal lesions of secondary hyperparathyroidism without increasing serum calcium levels in children treated with dialysis [35, 46, 47, 94-96]. 
Use of sevelamer $\mathrm{HCl}$ has also been shown to halt the progression of vascular calcification in patients on dialysis, in contrast to the worsening cardiovascular disease associated with long-term calcium-based binder therapy [47, 94]. Lower mortality rates have also been associated with the use of sevelamer over calcium [97].

Lanthanum carbonate is a non-calcium-containing, but metal-containing (lanthanum), phosphorus binding agent. Several studies have demonstrated that lanthanum carbonate effectively reduces serum phosphorous levels, and there are fewer hypercalcemic episodes than with calcium carbonate [98-100]. However, plasma lanthanum levels increase over time. Although levels return to baseline after withdrawal of the drug, bone lanthanum content increases during therapy and remains elevated at least a year after discontinuation of treatment [101]. Further evidence from experiments on rodents indicates progressive liver, bone, and growth plate accumulation [102]. Thus, although lanthanum carbonate is an effective phosphate binder, long-term therapy results in its accumulation in a number of tissues, the long term consequences of which have yet to be defined [103].

In select patient populations and dialysis centers which are able to perform daily hemodialysis, the use of phosphate binding medications may be decreased or entirely avoided. Daily hemodialysis has been demonstrated to normalize serum phosphate levels in these patients, leading to improved nutrition, improved growth, and decreased phosphate binder usage [104, 105].

\section{Secondary hyperparathyroidism}

$25(\mathrm{OH})$ vitamin $\mathrm{D}$ deficiency is common in children with CKD, and assessment and repletion is recommended for all children in stages 2 to $4 \mathrm{CKD}$ with secondary hyperparathyroidism. After repletion of native vitamin D stores, therapy with active vitamin D sterols is effective in suppressing PTH levels to the target range for the stage of CKD. Vitamin D sterols suppress PTH levels by two mechanisms: indirectly, through increased intestinal calcium absorption, and directly, via suppression of PTH gene transcription. Calcitriol and alfacalcidol are widely used in children, have been shown to be effective in suppressing PTH when given in daily or intermittent doses, and improve growth in children with CKD [39, 40]. However, hypercalcemia has been linked to their administration, particularly when given with calcium-containing phosphate binders. Thus, newer vitamin D analogues have been developed to maximize affinity for parathyroid tissue, while minimizing effects on intestinal calcium and phosphorus absorption. Three new vitamin D analogues are available for use in patients with CKD: 22-oxacalcitriol (OCT) in Japan, as well as 19-nor-1,25-dihydroxyvitamin $\mathrm{D}_{2}$ (paricalcitol) and
$1 \alpha$-hydroxyvitamin $\mathrm{D}_{2}$ (doxercalciferol) in the USA. Oral forms of paricalcitol and doxercalciferol have been approved for CKD 3 through 5 in adults, though not yet in children. Doxercalciferol and paricalcitol are effective in lowering PTH levels and may have a lower calcemic potential than calcitriol in both adults and children with CKD [35, 106].

Calcimimetic agents, which act as allosteric activators of the calcium sensing receptor (CaSR), are also available for the treatment of secondary hyperparathyroidism in the adult dialysis population. By increasing the sensitivity of the CaSR, these small organic molecules are able to reduce PTH levels, decrease the calcium-phosphorus product, and may provide a medical means of halting the progression of parathyroid gland hyperplasia [107]. Cinacalcet has been shown to be effective in the control of secondary hyperparathyroidism in adults with CKD [108], in those treated with maintenance dialysis [109-112], and in those with functioning renal allografts [113]. These agents have not been approved for use in children, and, due to the presence of the CaSR on the growth plate [114], studies are required to confirm their safety and efficacy in young patients.

\section{Growth}

Despite correction of acidosis and optimization of nutrition, many children with CKD continue to grow poorly. Recombinant growth hormone therapy may be indicated in those whose height is below the 5 th percentile for age and who have open epiphyseal plates. Skeletal X-rays to evaluate bone age are indicated prior to initiation of hormone therapy. Skeletal deformities, such as active rickets or slipped capital femoral epiphyses, should be allowed to heal prior to initiation of therapy. Furthermore, since growth hormone therapy may worsen secondary hyperparathyroidism, serum PTH levels must be well controlled prior to start of therapy and should be routinely monitored during treatment. Of note, the clinical response to recombinant growth hormone differs according to stage of CKD, children with stage 5 CKD displaying a less robust growth response than those with less severe kidney disease [115, 116]. Thus, many factors, including growth potential, degree of kidney failure, optimal dialysis prescription [105], concomitant morbidities, and control of renal osteodystrophy, should be considered prior to the initiation of growth hormone therapy.

Vascular disease

Since cardiovascular disease is the leading cause of death in both adults and children with CKD, the prevention of cardiovascular disease progression is crucial in the man- 
agement of the CKD-MBD. The etiology of vascular disease in CKD is multifactorial and includes traditional risk factors, such as hyperlipidemia, hypertension, and inflammation, as well as alterations in mineral metabolism specific to CKD; thus, treatment is also multifaceted. Lipid lowering agents are effective in reducing cardiac mortality in adults with CKD [117] and in those with stable renal allografts [118], although no benefit from their use has been established in patients treated with maintenance dialysis [119]. Normalization of mineral metabolism, by the avoidance of PTH over-suppression, avoidance of hypercalcemia, and the maintenance of normal serum phosphorus and the overall calcium $\times$ phosphorus product, is essential in all patients with CKD [18]. The limiting of total calcium intake to less than twice the DRI for age, in conjunction with the routine monitoring of biochemical parameters and adjustment of both phosphate binder and vitamin D sterol therapy, is recommended to prevent progressive vascular disease. Evaluation of vascular calcifications in children may be performed by ultrasound of carotid intimal-medial wall thickness [120]. The methodology for coronary electron beam computed tomography (EBCT) and the value of echocardiogram or abdominal X-rays [121], useful in the adult population, have not been well established in children.

\section{Questions (answers appear after the references)}

A 12-year-old boy has come to a pediatrician's office for a school physical. He wakes up several times at night to urinate. On examination, he is found to be a pale boy with a height and a weight that are both below the third percentile. He has Tanner 1 pubertal development and normal blood pressure. Serum electrolyte concentrations are: sodium $136 \mathrm{mmol} / \mathrm{l}$, potassium $3.8 \mathrm{mmol} / \mathrm{l}$, chloride $108 \mathrm{mmol} / \mathrm{l}$, total $\mathrm{CO}_{2} 18 \mathrm{mmol} / \mathrm{l}$, blood urea nitrogen (BUN) $40 \mathrm{mg} / \mathrm{dl}$, creatinine of $1.8 \mathrm{mg} / \mathrm{dl}$ (stage $3 \mathrm{CKD}$ ), phosphorus $4 \mathrm{mg} / \mathrm{dl}$, calcium $9.9 \mathrm{mg} / \mathrm{dl}$, PTH $170 \mathrm{pg} / \mathrm{ml}$, and a hematocrit of $28 \%$.

1. An appropriate serum PTH level for this child with this degree of renal insufficiency is:
a. $10-65 \mathrm{pg} / \mathrm{ml}$
b. $65-110 \mathrm{pg} / \mathrm{ml}$
c. $200-300 \mathrm{pg} / \mathrm{ml}$
d. $>400 \mathrm{pg} / \mathrm{ml}$

2. Appropriate management of his secondary hyperparathyroidism does not include:
a. measurement and repletion of $25(\mathrm{OH})$ vitamin $\mathrm{D}$
b. initiation of a calcium-free phosphate binder
c. dietary phosphate restriction
d. initiation of calcitriol therapy

3. Growth hormone therapy should be initiated:
a. immediately, to maximize final height potential
b. after correction of acidosis, anemia, and secondary hyperparathyroidism
c. after the initiation of dialysis
d. after successful renal transplantation
e. growth hormone therapy is contraindicated in this child

4. An 8-year-old girl presents with reflux nephropathy and growth failure and has the following serum biochemical determinations: serum creatinine $2.5 \mathrm{mg} / \mathrm{dl}$ (CKD stage 4), calcium $8.9 \mathrm{mg} / \mathrm{dl}$, phosphorus $6 \mathrm{mg} / \mathrm{dl}$, and PTH $140 \mathrm{pg} / \mathrm{ml}$. The first step in serum phosphorus management is:
a. initiation of a non-calcium-containing phosphate binder
b. nutritional assessment and phosphate restriction
c. vitamin D sterol therapy
d. growth hormone therapy

5. A 14-year-old boy with obstructive uropathy and stage $3 \mathrm{CKD}$ has been treated with growth hormone therapy for the past 2 years. His growth velocity has been decreasing over the past 6 months. An indication to stop therapy would be:
a. serum PTH level of $150 \mathrm{pg} / \mathrm{ml}$
b. height at $50 \%$ for age
c. Tanner 2 pubertal development
d. increasing alkaline phosphatase activity

6: A 10-year-old boy receiving maintenance hemodialysis is treated with calcium carbonate and thrice-weekly calcitriol to control his renal osteodystrophy. His serum PTH level is $700 \mathrm{pg} / \mathrm{ml}$, phosphorus $5 \mathrm{mg} / \mathrm{dl}$ and calcium is $11.5 \mathrm{mg} / \mathrm{dl}$. To ameliorate his hypercalcemia, the next step in his therapy should include:
a. dietary calcium restriction
b. bone biopsy
c. switching to a non-calcium-containing phosphate binder
d. increasing the calcitriol therapy

7. An 8-year-old girl with reflux nephropathy has stage 3 CKD and a height SD less than the 3rd percentile. Contraindication to starting GH therapy in this patient is:
a. serum PTH level of $900 \mathrm{pg} / \mathrm{ml}$
b. bone age of 6 years
c. weight $\mathrm{SD}$ at the $3 \mathrm{rd}$ percentile
d. recurrent urinary tract infections 
8. A 9-year-old boy on dialysis has a serum calcium level of $10.2 \mathrm{mg} / \mathrm{dl}$ and serum phosphorus of $7 \mathrm{mg} / \mathrm{dl}$. He currently receives two tablets of calcium carbonate $(500 \mathrm{mg})$ with each meal and snack (a total of eight tablets per day). Optimal control of his serum phosphorus could best be obtained by:
a. dietary protein restriction to $0.8 \mathrm{mg} / \mathrm{kg}$ per day
b. increasing his calcium carbonate to three tablets with meals and snacks
c. adding sevelamer to his phosphate binder regimen
d. increasing vitamin D sterol therapy
e. starting him on a calcimimetic

9. A 14-year-old boy with stage $4 \mathrm{CKD}$ has the following serum biochemical determinations: phosphorus $5.8 \mathrm{mg} /$ $\mathrm{dl}$, calcium $9 \mathrm{mg} / \mathrm{dl}$, and PTH $160 \mathrm{pg} / \mathrm{ml}$. The following intervention is not recommended at this stage of his treatment:
a. calcium carbonate with meals
b. lanthanum carbonate with meals
c. low-dose calcitriol, nightly
d. dietary phosphate restriction

\section{References}

1. Moe S, Drueke T, Cunningham J, Goodman W, Martin K, Olgaard K, Ott S, Sprague S, Lameire N, Eknoyan G (2006) Definition, evaluation, and classification of renal osteodystrophy: a position statement from Kidney Disease: Improving Global Outcomes (KDIGO). Kidney Int 69:1945-1953

2. Martinez I, Saracho R, Montenegro J, Llach F (1996) A deficit of calcitriol synthesis may not be the initial factor in the pathogenesis of secondary hyperparathyroidism. Nephrol Dial Transplant 11 [Suppl 3]:22-28

3. Levin A, Bakris GL, Molitch M, Smulders M, Tian J, Williams LA, Andress DL (2007) Prevalence of abnormal serum vitamin D, PTH, calcium, and phosphorus in patients with chronic kidney disease: results of the study to evaluate early kidney disease. Kidney Int 71:31-38

4. Fraser DR, Kodicek E (1970) Unique biosynthesis by kidney of a biological active vitamin D metabolite. Nature 228:764-766

5. Gray R, Boyle I, DeLuca HF (1971) Vitamin D metabolism: the role of kidney tissue. Science 172:1232-1234

6. Norman AW (1971) Evidence for a new kidney-produced hormone, 1,25-dihydroxycholecalciferol, the proposed biologically active form of vitamin D. Am J Clin Nutr 24:1346-1351

7. Svensson O, Wernerson A, Reinholt FP (1988) Effect of calcium depletion on the rat parathyroids. Bone Miner 3:259-269

8. Wernerson A, Widholm SM, Svensson O, Reinholt FP (1991) Parathyroid cell number and size in hypocalcemic young rats. APMIS 99:1096-1102

9. Martinez I, Saracho R, Montenegro J, Llach F (1997) The importance of dietary calcium and phosphorous in the secondary hyperparathyroidism of patients with early renal failure. Am J Kidney Dis 29:496-502

10. Portale AA, Booth BE, Halloran BP, Morris RC Jr (1984) Effect of dietary phosphorus on circulating concentrations of $1,25-$ dihydroxyvitamin $\mathrm{D}$ and immunoreactive parathyroid hormone in children with moderate renal insufficiency. J Clin Invest 73:1580-1589

11. Almaden Y, Canalejo A, Ballesteros E, Anon G, Canadillas S, Rodriguez M (2002) Regulation of arachidonic acid production by intracellular calcium in parathyroid cells: effect of extracellular phosphate. J Am Soc Nephrol 13:693-698

12. Naveh-Many T, Bell O, Silver J, Kilav R (2002) Cis and trans acting factors in the regulation of parathyroid hormone (PTH) mRNA stability by calcium and phosphate. FEBS Lett 529:60-64

13. Massry SG, Coburn JW, Lee DB, Jowsey J, Kleeman CR (1973) Skeletal resistance to parathyroid hormone in renal failure. Studies in 105 human subjects. Ann Intern Med 78:357-364

14. Naveh-Many T, Rahamimov R, Livni N, Silver J (1995) Parathyroid cell proliferation in normal and chronic renal failure rats. The effects of calcium, phosphate, and vitamin D. J Clin Invest 96:1786-1793

15. Lloyd HM, Parfitt AM, Jacobi JM, Willgoss DA, Craswell PW, Petrie JJ, Boyle PD (1989) The parathyroid glands in chronic renal failure: a study of their growth and other properties made on the basis of findings in patients with hypercalcemia. J Lab Clin Med 114:358-367

16. Larsson $\mathrm{T}$, Nisbeth $\mathrm{U}$, Ljunggren $\mathrm{O}$, Juppner $\mathrm{H}$, Jonsson $\mathrm{KB}$ (2003) Circulating concentration of FGF-23 increases as renal function declines in patients with chronic kidney disease, but does not change in response to variation in phosphate intake in healthy volunteers. Kidney Int 64:2272-2279

17. Gutierrez O, Isakova T, Rhee E, Shah A, Holmes J, Collerone G, Jüppner H, Wolf M (2005) Fibroblast growth factor-23 mitigates hyperphosphatemia but accentuates calcitriol deficiency in chronic kidney disease. J Am Soc Nephrol 16:2205-2215

18. National Kidney Foundation (2005) K/DOQI clinical practice guidelines for bone metabolism and disease in children with chronic kidney disease. Am J Kidney Dis 46 [4 Suppl 1]:S1-121

19. Norris KC, Goodman WG, Howard N, Nugent ME, Coburn JW (1986) Iliac crest bone biopsy for diagnosis of aluminum toxicity and a guide to the use of deferoxamine. Semin Nephrol $6[4$ Suppl 1]:27-34

20. Salusky IB, Coburn JW, Brill J, Foley J, Slatopolsky E, Fine RN, Goodman WG (1988) Bone disease in pediatric patients undergoing dialysis with CAPD or CCPD. Kidney Int 33:975982

21. Atkins D, Peacock M (1975) A comparison of the effects of the calcitonins, steroid hormones and thyroid hormones on the response of bone to parathyroid hormone in tissue culture. J Endocrinol 64:573-583

22. Lee K, Deeds JD, Bond AT, Juppner H, Abou-Samra AB, Segre GV (1993) In situ localization of PTH/PTHrP receptor mRNA in the bone of fetal and young rats. Bone 14:341-345

23. Sherrard DJ (1986) Renal osteodystrophy. Semin Nephrol 6: $56-67$

24. Groothoff JW, Offringa M, Van Eck-Smit BL, Gruppen MP, Van De Kar NJ, Wolff ED, Lilien MR, Davin JC, Heymans HS, Dekker FW (2003) Severe bone disease and low bone mineral density after juvenile renal failure. Kidney Int 63:266-275

25. Malluche H, Faugere MC (1990) Renal bone disease 1990: an unmet challenge for the nephrologist. Kidney Int 8:193-211

26. Hamdy NA, Kanis JA, Beneton MN, Brown CB, Juttmann JR, Jordans JG, Josse S, Meyrier A, Lins RL, Fairey IT (1995) Effect of alfacalcidol on natural course of renal bone disease in mild to moderate renal failure. BMJ 310:358-363

27. Salusky IB, Coburn JW, Foley J, Nelson P, Fine RN (1986) Effects of oral calcium carbonate on control of serum phosphorus and changes in plasma aluminum levels after discontinuation of aluminum-containing gels in children receiving dialysis. J Pediatr 108:767-770 
28. Goodman WG, Ramirez JA, Belin TR, Chon Y, Gales B, Segre GV, Salusky IB (1994) Development of adynamic bone in patients with secondary hyperparathyroidism after intermittent calcitriol therapy. Kidney Int 46:1160-1166

29. Ott SM, Maloney NA, Klein GL, Alfrey AC, Ament ME, Coburn JW, Sherrard DJ (1983) Aluminum is associated with low bone formation in patients receiving chronic parenteral nutrition. Ann Intern Med 98:910-914

30. London GM, Marty C, Marchais SJ, Guerin AP, Metivier F, de Vernejoul MC (2004) Arterial calcifications and bone histomorphometry in end-stage renal disease. J Am Soc Nephrol 15:1943-1951

31. Kuizon BD, Salusky IB (1998) Intermittent calcitriol therapy and growth in children with chronic renal failure. Miner Electrolyte Metab 24:290-295

32. Kuizon BD, Goodman WG, Juppner H, Boechat I, Nelson P, Gales B, Salusky IB (1998) Diminished linear growth during intermittent calcitriol therapy in children undergoing CCPD. Kidney Int 53:205-211

33. Salusky IB, Ramirez JA, Oppenheim W, Gales B, Segre GV, Goodman WG (1994) Biochemical markers of renal osteodystrophy in pediatric patients undergoing CAPD/CCPD. Kidney Int 45:253-258

34. Salusky IB, Goodman WG, Kuizon BD, Lavigne JR, Zahranik RJ, Gales B, Wang HJ, Elashoff RM, Jüppner H (2003) Similar predictive value of bone turnover using first- and secondgeneration immunometric PTH assays in pediatric patients treated with peritoneal dialysis. Kidney Int 63:1801-1808

35. Salusky IB, Goodman WG, Sahney S, Gales B, Perilloux A, Wang HJ, Elashoff RM, Jüppner H (2005) Sevelamer controls parathyroid hormone-induced bone disease as efficiently as calcium carbonate without increasing serum calcium levels during therapy with active vitamin D sterols. J Am Soc Nephrol 16:2501-2508

36. Ho AY, Kung AW (2005) Determinants of peak bone mineral density and bone area in young women. J Bone Miner Metab $23: 470-475$

37. Tonshoff B, Schaefer F, Mehls O (1990) Disturbance of growth hormone-insulin-like growth factor axis in uraemia. Implications for recombinant human growth hormone treatment. Pediatr Nephrol 4:654-662

38. North American Pediatric Renal Transplant Cooperative (2006) North American Pediatric Renal Transplant Cooperative Study (NAPRTCS) 2006 Annual report

39. Waller SC, Ridout D, Cantor T, Rees L (2005) Parathyroid hormone and growth in children with chronic renal failure. Kidney Int 67:2338-2345

40. Schmitt CP, Ardissino G, Testa S, Claris-Appiani A, Mehls O (2003) Growth in children with chronic renal failure on intermittent versus daily calcitriol. Pediatr Nephrol 18:440-444

41. Klaus G, Watson A, Edefonti A, Fischbach M, Rönnholm K, Schaefer F, Simkova E, Stefanidis CJ, Strazdins V, Vande Walle J, Schröder C, Zurowska A, Ekim M, European Pediatric Dialysis Working Group (EPDWG) (2006) Prevention and treatment of renal osteodystrophy in children on chronic renal failure: European guidelines. Pediatr Nephrol 21:151-159

42. Tonshoff B, Cronin MJ, Reichert M, Haffner D, Wingen AM, Blum WF, Mehls O (1997) Reduced concentration of serum growth hormone $(\mathrm{GH})$-binding protein in children with chronic renal failure: correlation with GH insensitivity. The European Study Group for Nutritional Treatment of Chronic Renal Failure in Childhood. The German Study Group for Growth Hormone Treatment in Chronic Renal Failure. J Clin Endocrinol Metab 82:1007-1013
43. Tonshoff B, Blum WF, Mehls O (1997) Derangements of the somatotropic hormone axis in chronic renal failure. Kidney Int Suppl 58:S106-S113

44. Powell DR, Durham SK, Liu F, Baker BK, Lee PD, Watkins SL, Campbell PG, Brewer ED, Hintz RL, Hogg RJ (1998) The insulin-like growth factor axis and growth in children with chronic renal failure: a report of the Southwest Pediatric Nephrology Study Group. J Clin Endocrinol Metab 83:1654 1661

45. Mehls O, Ritz E, Krempien B, Gilli G, Link K, Willich E, Schärer K (1975) Slipped epiphyses in renal osteodystrophy. Arch Dis Child 50:545-554

46. Chertow GM, Burke SK, Raggi P (2002) Sevelamer attenuates the progression of coronary and aortic calcification in hemodialysis patients. Kidney Int 62:245-252

47. Block GA, Spiegel DM, Ehrlich J, Mehta R, Lindbergh J, Dreisbach A, Raggi P (2005) Effects of sevelamer and calcium on coronary artery calcification in patients new to hemodialysis. Kidney Int 68:1815-1824

48. Milliner DS, Zinsmeister AR, Lieberman E, Landing B (1990) Soft tissue calcification in pediatric patients with end-stage renal disease. Kidney Int 38:931-936

49. Goodman WG, Goldin J, Kuizon BD, Yoon C, Gales B, Sider D, Wang Y, Chung J, Emerick A, Greaser L, Elashoff RM, Salusky IB (2000) Coronary-artery calcification in young adults with end-stage renal disease who are undergoing dialysis. N Engl J Med 342:1478-1483

50. Chertow GM, Raggi P, Chasan-Taber S, Bommer J, Holzer H, Burke SK (2004) Determinants of progressive vascular calcification in haemodialysis patients. Nephrol Dial Transplant 19:1489-1496

51. van Renen MJ, Hogg RJ, Sweeney AL, Henning PH, Penfold JL, Jureidini KF (1992) Accelerated growth in short children with chronic renal failure treated with both strict dietary therapy and recombinant growth hormone. Pediatr Nephrol 6:451-458

52. Charhon SA, Delmas PD, Malaval L, Chavassieux PM, Arlot M, Chapuy MC, Meunier PJ (1986) Serum bone Gla-protein in renal osteodystrophy: comparison with bone histomorphometry. J Clin Endocrinol Metab 63:892-897

53. Sherrard DJ, Hercz G, Pei Y, Maloney NA, Greenwood C, Manuel A, Saiphoo C, Fenton SS, Segre GV (1993) The spectrum of bone disease in end-stage renal failure-an evolving disorder. Kidney Int 43:436-442

54. Monier-Faugere MC, Geng Z, Mawad H, Friedler RM, Gao P, Cantor TL, Malluche HH (2001) Improved assessment of bone turnover by the PTH-(1-84)/large C-PTH fragments ratio in ESRD patients. Kidney Int 60:1460-1468

55. Coen G, Bonucci E, Ballanti P, Balducci A, Calabria S, Nicolai GA, Fischer MS, Lifrieri F, Manni M, Morosetti M, Moscaritolo E, Sardella D (2002) PTH 1-84 and PTH "7-84" in the noninvasive diagnosis of renal bone disease. Am J Kidney Dis 40:348-354

56. Pitts TO, Piraino BH, Mitro R, Chen TC, Segre GV, Greenberg A, Puschett JB (1988) Hyperparathyroidism and 1,25dihydroxyvitamin $\mathrm{D}$ deficiency in mild, moderate, and severe renal failure. J Clin Endocrinol Metab 67:876-881

57. Sanchez CP, Salusky IB, Kuizon BD, Abdella P, Juppner H, Goodman WG (1998) Growth of long bones in renal failure: roles of hyperparathyroidism, growth hormone and calcitriol. Kidney Int 54:1879-1887

58. Avbersek-Luznik I, Malesic I, Rus I, Marc J (2002) Increased levels of osteoprotegerin in hemodialysis patients. Clin Chem Lab Med 40:1019-1023

59. Kazama JJ, Shigematsu T, Yano K, Tsuda E, Miura M, Iwasaki Y, Kawaguchi Y, Gejyo F, Kurokawa K, Fukagawa M (2002) 
Increased circulating levels of osteoclastogenesis inhibitory factor (osteoprotegerin) in patients with chronic renal failure. Am J Kidney Dis 39:525-532

60. Waller S, Ledermann S, Trompeter R, van't Hoff W, Ridout D, Rees L (2003) Catch-up growth with normal parathyroid hormone levels in chronic renal failure. Pediatr Nephrol 18:1236-1241

61. Gordon CM, DePeter KC, Feldman HA, Grace E, Emans SJ (2004) Prevalence of vitamin D deficiency among healthy adolescents. Arch Pediatr Adolesc Med 158:531-537

62. DeVille J, Thorp ML, Tobin L, Gray E, Johnson ES, Smith DH (2006) Effect of ergocalciferol supplementation on serum parathyroid hormone and serum 25-hydroxyvitamin $\mathrm{D}$ in chronic kidney disease. Nephrology (Carlton) 11:555-559

63. Zisman AL, Hristova M, Ho LT, Sprague SM (2007) Impact of ergocalciferol treatment of vitamin D deficiency on serum parathyroid hormone concentrations in chronic kidney disease. Am J Nephrol 27:36-43

64. Langman CB, Mazur AT, Baron R, Norman ME (1982) 25hydroxyvitamin D3 (calcifediol) therapy of juvenile renal osteodystrophy: beneficial effect on linear growth velocity. J Pediatr 100:815-820

65. Bowe AE, Finnegan R, Jan de Beur SM, Cho J, Levine MA, Kumar R, Schiavi SC (2001) FGF-23 inhibits renal tubular phosphate transport and is a PHEX substrate. Biochem Biophys Res Commun 284:977-981

66. ADHR Consortium (2000) Autosomal dominant hypophosphataemic rickets is associated with mutations in FGF23. Nat Genet 26:345-348

67. De Beur SM, Finnegan RB, Vassiliadis J, Cook B, Barberio D, Estes S, Manavalan P, Petroziello J, Madden SL, Cho JY, Kumar R, Levine MA, Schiavi SC (2002) Tumors associated with oncogenic osteomalacia express genes important in bone and mineral metabolism. J Bone Miner Res 17:1102-1110

68. Yamazaki Y, Okazaki R, Shibata M, Hasegawa Y, Satoh K, Tajima T, Takeuchi Y, Fujita T, Nakahara K, Yamashita T, Fukumoto S (2002) Increased circulatory level of biologically active full-length FGF-23 in patients with hypophosphatemic rickets/osteomalacia. J Clin Endocrinol Metab 87:4957-4960

69. Antoniucci DM, Yamashita T, Portale AA (2006) Dietary phosphorus regulates serum fibroblast growth factor-23 concentrations in healthy men. J Clin Endocrinol Metab 91:3144-3149

70. Burnett SA, Gunawardene SC, Bringhurst FR, Juppner H, Lee H, Finkelstein JS (2006) Regulation of C-terminal and intact FGF-23 by dietary phosphate in men and women. J Bone Miner Res 21:1187-1196

71. Nishi H, Nii-Kono T, Nakanishi S, Yamazaki Y, Yamashita T, Fukumoto S, Ikeda K, Fujimori A, Fukagawa M (2005) Intravenous calcitriol therapy increases serum concentrations of fibroblast growth factor- 23 in dialysis patients with secondary hyperparathyroidism. Nephron Clin Pract 101:c94-c99

72. Kazama JJ, Sato F, Omori K, Hama H, Yamamoto S, Maruyama H, Narita I, Gejyo F, Yamashita T, Fukumoto S, Fukagawa M (2005) Pretreatment serum FGF-23 levels predict the efficacy of calcitriol therapy in dialysis patients. Kidney Int 67:1120-1125

73. Nakanishi S, Kazama JJ, Nii-Kono T, Omori K, Yamashita T, Fukumoto S, Gejyo F, Shigematsu T, Fukagawa M (2005) Serum fibroblast growth factor-23 levels predict the future refractory hyperparathyroidism in dialysis patients. Kidney Int 67:11711178

74. Goldsmith DJ, Covic A, Sambrook PA, Ackrill P (1997) Vascular calcification in long-term haemodialysis patients in a single unit: a retrospective analysis. Nephron 77:37-43

75. Ketteler M, Bongartz P, Westenfeld R, Wildberger JE, Mahnken AH, Böhm R, Metzger T, Wanner C, Jahnen-Dechent W, Floege $\mathrm{J}$ (2003) Association of low fetuin-A (AHSG) concentrations in serum with cardiovascular mortality in patients on dialysis: a cross-sectional study. Lancet 361:827-833

76. Russo D, Palmiero G, De Blasio AP, Balletta MM, Andreucci VE (2004) Coronary artery calcification in patients with CRF not undergoing dialysis. Am J Kidney Dis 44:1024-1030

77. Mitsnefes MM, Kimball TR, Kartal J, Witt SA, Glascock BJ, Khoury PR, Daniels SR (2005) Cardiac and vascular adaptation in pediatric patients with chronic kidney disease: role of calcium-phosphorus metabolism. J Am Soc Nephrol 16:27962803

78. Chavers BM, Li S, Collins AJ, Herzog CA (2002) Cardiovascular disease in pediatric chronic dialysis patients. Kidney Int 62:648-653

79. Ducy P, Zhang R, Geoffroy V, Ridall AL, Karsenty G (1997) Osf $2 / \mathrm{Cbfa} 1$ : a transcriptional activator of osteoblast differentiation. Cell 89:747-754

80. Moe SM, Duan D, Doehle BP, O'Neill KD, Chen NX (2003) Uremia induces the osteoblast differentiation factor Cbfa1 in human blood vessels. Kidney Int 63:1003-1011

81. Jono S, McKee MD, Murry CE, Shioi A, Nishizawa Y, Mori K, Morii H, Giachelli CM (2000) Phosphate regulation of vascular smooth muscle cell calcification. Circ Res 87:E10-E17

82. Mizobuchi M, Ogata H, Hatamura I, Koiwa F, Saji F, Shiizaki K, Negi S, Kinugasa E, Ooshima A, Koshikawa S, Akizawa T (2006) Up-regulation of Cbfal and Pit-1 in calcified artery of uraemic rats with severe hyperphosphataemia and secondary hyperparathyroidism. Nephrol Dial Transplant 21:911-916

83. Ahmed S, O'Neill KD, Hood AF, Evan AP, Moe SM (2001) Calciphylaxis is associated with hyperphosphatemia and increased osteopontin expression by vascular smooth muscle cells. Am J Kidney Dis 37:1267-1276

84. Bostrom K (2001) Insights into the mechanism of vascular calcification. Am J Cardiol 88:20E-22E

85. Moe SM, O'Neill KD, Duan D, Ahmed S, Chen NX, Leapman SB, Fineberg N, Kopecky K (2002) Medial artery calcification in ESRD patients is associated with deposition of bone matrix proteins. Kidney Int 61:638-647

86. Chen NX, O'Neill KD, Duan D, Moe SM (2002) Phosphorus and uremic serum up-regulate osteopontin expression in vascular smooth muscle cells. Kidney Int 62:1724-1731

87. Schinke T, Amendt C, Trindl A, Poschke O, Muller-Esterl W, Jahnen-Dechent W (1996) The serum protein alpha2-HS glycoprotein/fetuin inhibits apatite formation in vitro and in mineralizing calvaria cells. A possible role in mineralization and calcium homeostasis. J Biol Chem 271:20789-20796

88. Sweatt A, Sane DC, Hutson SM, Wallin R (2003) Matrix Gla protein (MGP) and bone morphogenetic protein-2 in aortic calcified lesions of aging rats. J Thromb Haemost 1:178-185

89. Schafer C, Heiss A, Schwarz A, Westenfeld R, Ketteler M, Floege J, Muller-Esterl W, Schinke T, Jahnen-Dechent W (2003) The serum protein alpha 2-Heremans-Schmid glycoprotein/ fetuin-A is a systemically acting inhibitor of ectopic calcification. J Clin Invest 112:357-366

90. Inaba M, Okuno S, Imanishi Y, Yamada S, Shioi A, Yamakawa T, Ishimura E, Nishizawa Y (2006) Role of fibroblast growth factor-23 in peripheral vascular calcification in non-diabetic and diabetic hemodialysis patients. Osteoporos Int 17:1506-1513

91. Levin A, Bakris GL, Molitch M, Smulders M, Tian J, Williams LA, Andress DL (2007) Prevalence of abnormal serum vitamin D, PTH, calcium, and phosphorus in patients with chronic kidney disease: results of the study to evaluate early kidney disease. Kidney Int 71:31-38

92. Alon U, Davidai G, Bentur L, Berant M, Better OS (1986) Oral calcium carbonate as phosphate-binder in infants and children with chronic renal failure. Miner Electrolyte Metab 12:320-325 
93. Andreoli SP, Dunson JW, Bergstein JM (1987) Calcium carbonate is an effective phosphorus binder in children with chronic renal failure. Am J Kidney Dis 9:206-210

94. Mahdavi H, Kuizon BD, Gales B, Wang HJ, Elashoff RM, Salusky IB (2003) Sevelamer hydrochloride: an effective phosphate binder in dialyzed children. Pediatr Nephrol 18:1260-1264

95. Slatopolsky EA, Burke SK, Dillon MA (1999) RenaGel, a nonabsorbed calcium- and aluminum-free phosphate binder, lowers serum phosphorus and parathyroid hormone. The RenaGel Study Group. Kidney Int 55:299-307

96. Bleyer AJ, Burke SK, Dillon M, Garrett B, Kant KS, Lynch D, Rahman SN, Schoenfeld P, Teitelbaum I, Zeig S, Slatopolsky E (1999) A comparison of the calcium-free phosphate binder sevelamer hydrochloride with calcium acetate in the treatment of hyperphosphatemia in hemodialysis patients. Am J Kidney Dis 33:694-701

97. Block GA, Raggi P, Bellasi A, Kooienga L, Spiegel DM (2007) Mortality effect of coronary calcification and phosphate binder choice in incident hemodialysis patients. Kidney Int 71:438-441

98. D'Haese PC, Spasovski GB, Sikole A, Hutchison A, Freemont TJ, Sulkova S, Swanepoel C, Pejanovic S, Djukanovic L, Balducci A, Coen G, Sulowicz W, Ferreira A, Torres A, Curic S, Popovic M, Dimkovic N, De Broe ME (2003) A multicenter study on the effects of lanthanum carbonate (Fosrenol) and calcium carbonate on renal bone disease in dialysis patients. Kidney Int 63 [Suppl 85]:73-78

99. Hutchison AJ, Speake M, Al-Baaj F (2004) Reducing high phosphate levels in patients with chronic renal failure undergoing dialysis: a 4-week, dose-finding, open-label study with lanthanum carbonate. Nephrol Dial Transplant 19:1902-1906

100. Finn WF, Joy MS, Hladik G (2004) Efficacy and safety of lanthanum carbonate for reduction of serum phosphorus in patients with chronic renal failure receiving hemodialysis. Clin Nephrol 62:193-201

101. Spasovski GB, Sikole A, Gelev S, Masin-Spasovska J, Freemont T, Webster I, Gill M, Jones C, De Broe ME, D'Haese PC (2006) Evolution of bone and plasma concentration of lanthanum in dialysis patients before, during 1 year of treatment with lanthanum carbonate and after 2 years of follow-up. Nephrol Dial Transplant 21:2217-2224

102. Slatopolsky E, Liapis H, Finch J (2005) Progressive accumulation of lanthanum in the liver of normal and uremic rats. Kidney Int 68:2809-2813

103. Shire Pharmaceuticals (2004) Fosrenol (lanthanum carbonate). Product package insert

104. Tom A, McCauley L, Bell L, Rodd C, Espinosa P, Yu G, Yu J, Girardin C, Sharma A (1999) Growth during maintenance hemodialysis: impact of enhanced nutrition and clearance. J Pediatr 134:464-471

105. Fischbach M, Terzic J, Menouer S, Dheu C, Soskin S, Helmstetter A, Burger MC (2006) Intensified and daily hemodialysis in children might improve statural growth. Pediatr Nephrol 21:1746-1752

106. Coburn JW, Maung HM, Elangovan L, Germain MJ, Lindberg JS, Sprague SM, Williams ME, Bishop CW (2004) Doxercalciferol safely suppresses PTH levels in patients with secondary hyperparathyroidism associated with chronic kidney disease stages 3 and 4. Am J Kidney Dis 43:877-890

107. Wada M, Nagano N (2003) Control of parathyroid cell growth by calcimimetics. Nephrol Dial Transplant 18 [Suppl 3]:iii13-iii17

108. Charytan C, Coburn JW, Chonchol M, Herman J, Lien YH, Liu W, Klassen PS, McCary LC, Pichette V (2005) Cinacalcet hydrochloride is an effective treatment for secondary hyperparathyroidism in patients with $\mathrm{CKD}$ not receiving dialysis. Am J Kidney Dis 46:58-67
109. Goodman WG, Hladik GA, Turner SA, Blaisdell PW, Goodkin DA, Liu W, Barri YM, Cohen RM, Coburn JW (2002) The calcimimetic agent AMG 073 lowers plasma parathyroid hormone levels in hemodialysis patients with secondary hyperparathyroidism. J Am Soc Nephrol 13:1017-1024

110. Block GA, Martin KJ, de Francisco AL, Turner SA, Avram MM, Suranyi MG, Hercz G, Cunningham J, Abu-Alfa AK, Messa P, Coyne DW, Locatelli F, Cohen RM, Evenepoel P, Moe SM, Fournier A, Braun J, McCary LC, Zani VJ, Olson KA, Drüeke TB, Goodman WG (2004) Cinacalcet for secondary hyperparathyroidism in patients receiving hemodialysis. N Engl J Med 350:1516-1525

111. Lindberg JS, Culleton B, Wong G, Borah MF, Clark RV, Shapiro WB, Roger SD, Husserl FE, Klassen PS, Guo MD, Albizem MB, Coburn JW (2005) Cinacalcet $\mathrm{HCl}$, an oral calcimimetic agent for the treatment of secondary hyperparathyroidism in hemodialysis and peritoneal dialysis: a randomized, double-blind, multicenter study. J Am Soc Nephrol 16:800-807

112. Martin KJ, Juppner H, Sherrard DJ, Goodman WG, Kaplan MR, Nassar G, Campbell P, Curzi M, Charytan C, McCary LC, Guo MD, Turner SA, Bushinsky DA (2005) First- and secondgeneration immunometric PTH assays during treatment of hyperparathyroidism with cinacalcet $\mathrm{HCl}$. Kidney Int 68:12361243

113. Serra AL, Schwarz AA, Wick FH, Marti HP, Wuthrich RP (2005) Successful treatment of hypercalcemia with cinacalcet in renal transplant recipients with persistent hyperparathyroidism. Nephrol Dial Transplant 20:1315-1319

114. Chang W, Tu C, Bajra R, Komuves L, Miller S, Strewler G, Shoback D (1999) Calcium sensing in cultured chondrogenic RCJ3.1C5.18 cells. Endocrinology 140:1911-1919

115. Schaefer F, Wuhl E, Haffner D, Mehls O (1994) Stimulation of growth by recombinant human growth hormone in children undergoing peritoneal or hemodialysis treatment. German Study Group for Growth Hormone Treatment in Chronic Renal Failure. Adv Perit Dial 10:321-326

116. Fine RN, Kohaut EC, Brown D, Perlman AJ (1994) Growth after recombinant human growth hormone treatment in children with chronic renal failure: report of a multicenter randomized doubleblind placebo-controlled study. Genentech Cooperative Study Group. J Pediatr 124:374-382

117. Tonelli M, Keech A, Shepherd J, Sacks F, Tonkin A, Packard C, Pfeffer M, Simes J, Isles C, Furberg C, West M, Craven T, Curhan G (2005) Effect of pravastatin in people with diabetes and chronic kidney disease. J Am Soc Nephrol 16:3748-3754

118. Holdaas H, Fellstrom B, Cole E, Nyberg G, Olsson AG, Pedersen TR, Madsen S, Grönhagen-Riska C, Neumayer HH, Maes B, Ambühl P, Hartmann A, Staffler B, Jardine AG, Assessment of LEscol in Renal Transplantation (ALERT) Study Investigators (2005) Long-term cardiac outcomes in renal transplant recipients receiving fluvastatin: the ALERT extension study. Am J Transplant 5:2929-2936

119. Wanner C, Krane V, Marz W, Olschewski M, Mann JF, Ruf G, Ritz E; German Diabetes and Dialysis Study Investigators (2005) Atorvastatin in patients with type 2 diabetes mellitus undergoing hemodialysis. N Engl J Med 353:238-248

120. Oh J, Wunsch R, Turzer M, Bahner M, Raggi P, Querfeld U, Mehls O, Schaefer F (2002) Advanced coronary and carotid arteriopathy in young adults with childhood-onset chronic renal failure. Circulation 106:100-105

121. Raggi P, Bellasi A, Ferramosca E, Islam T, Muntner P, Block GA (2007) Association of pulse wave velocity with vascular and valvular calcification in hemodialysis patients. Kidney Int 1:802-807 


\section{Answers}

1. a $(10-65 \mathrm{pg} / \mathrm{ml})$

2. $\mathrm{b}$ (initiate calcium-free phosphate binder)

3. b (after correction of acidosis, anemia and secondary hyperparathyroidism)
4. $\mathrm{b}$ (nutritional assessment and phosphate restriction)

5. b (height $50 \%$ for age)

6. c (switching to non-calcium phosphate binder)

7. a (serum PTH 900 pg/ml)

8. c (add sevelamer)

9. b (lanthanum carbonate) 